\title{
The Study of Residual Stresses in the Surface Layer
}

\author{
Piotr Kuryło \\ University of Zielona Góra, Faculty of Mechanical Engineering, Institute of Mechanical Engineering and Machine Operation, 65-001 Zielona \\ Gora, Licealna 9 street, Poland
}

\section{BIOGRAPHICAL NOTES}

PhD eng. Piotr Kurylo was born in 1966 in Zielona Gora, Lecturer at University of Zielona Gora. Assistant Professor in Faculty of Mechanical Engineering University of Zielona Gora. Completed his doctorate at the University of Poznan. Member of the Faculty of Mechanical Engineering. Specialist professional engineering, engineering of the surface layer, automation and robotics, manufacturing technologies.

\section{KEY WORDS}

Surface layer, spheroidal cast iron, stress pattern.

\section{ABSTRACT}

This essay synthetically presents a selection of technological properties of ENGJS-500-7 Spheroidal cast iron castings and a selection of applications of spheroidal cast iron in the function of its chemical composition. The concept of the surface layer (SL) was defined, its classification and basic elements of its structure were provided. The essay presents the results of the Davidenkov's method research on internal stresses in the surface layer of the cast iron castings (in weld surfaced half products appropriated for preforms and glass moulds). The results of the research clearly show that the values of stresses occurring during weld surfacing depend on the thickness of the weld surfaced layer. Moreover, the research has determined an important influence of the thickness of this layer on the stresses in the base material (core).

\section{Introduction}

The development of the contemporary knowledge on the subject of the basic properties of the construction materials is connected to the ever growing demand of the machine industry. The industry demands materials with specific properties, structure and chemical composition. Meeting these demands is not easy, but it contributes to developing new materials with altered properties. Researches in this field may generally follow three paths. The first way is to modify the chemical composition and the structure, as a result of which a completely new material is created, with modified technological and exploitation properties. The second way is to utilize the existing structure and chemical composition while optimizing e.g. technological allowances. The third way is to alter the properties of the material by way of various machining methods - from thermal machining, thermo-chemical machining to plastic processing. The criteria for implementation of alterations in the properties are generally defined in the construction planning phase. Material designing approach, which takes into account the constructional, technological and exploitational aspects, supported by modern construction optimization methods, guarantees creation of a modern construction material. Discovering the reasons behind the stresses occurring in materials 
during the process of creation of the technological surface layer and during its exploitation is particularly significant in contemporary technology. Well established knowledge about stresses significantly improves the development of methods and possibilities of their minimization or elimination. Therefore, it is crucial to take notice of the comprehensiveness when designing specific properties (e.g. resistance) of the contemporary construction materials.

\section{Characteristics of Spheroidal Cast Iron}

Graphite is a nonmetallic structural component of cast iron which causes the discontinuity of the metallic matrix, therefore its influence on the mechanical properties is definitely negative. The resistance of the cast iron, especially flake graphite grey cast iron is lower than the resistance of steel. Cast iron is relatively brittle and generally not ductile. In practice, cast iron with low content of carbon is used (usually not higher than $4 \%$ of total carbon with $3 \%$ of graphite). The properties of cast iron are influenced not only by the amount of graphite, but also by its size, shape and distribution. The best properties are exhibited by the cast iron with small content of graphite in a form of evenly distributed, small, isolated inclusions. In such cast iron, the weakening of the metallic matrix is least visible, and its resistance is close to that of steel. Whereas, the thicker the graphite inclusions get, the worse are the properties of the cast iron. The worst mechanical properties are exhibited by the cast iron with graphite in the form of large flakes, which by touching each other create a structure similar to a compact skeleton. As the shape of the graphite inclusions gets rounded, their negative effect on the properties of cast iron decreases. The nodular form of the graphite inclusions allows to obtain very resistant cast iron with good ductile properties. The properties of spheroidal cast iron, such as compressive strength or hardness, which are mainly dependent on the structure of the metallic matrix, are close to the properties of steel $[3$, 28, 31].

\section{Technological Properties}

Graphite increases the founding properties of the cast iron (grey cast iron is highly fluid and its casting shrinkage is small). The increase in the volume, which occurs during the creation of graphite, is advantageous in filling up the casting moulds during the solidification. The existence of the graphite inclusions improves machinability of the cast iron by making the swarf brittle. The graphite improves abrasive hardness of the cast iron, which allows to use it for example as a bearing material in such case chipped graphite mixes with grease, thus improving its properties. The pores, remaining on the surface of the cast iron serve as containers of the grease, supporting the abrasive surfaces. The graphite, especially in the form of flakes, reduces vibrations $[4,28]$.

\section{A Selection of Applications of Spheroidal Cast Iron as a Construction Material}

Castings are used in various constructions. Often they are the fundamental element of a machine or a device. Among others, cast iron castings are applied in:

- construction industry: sewer and waterworks fittings and pipes, radiators, sanitary facilities, etc.,

- power industry: combustion and steam engine blocks, cylinders, pistons, piston rings, engine bodies, crankshafts, valves, adjusters, flywheels, transmission gears and their cases, parts of boilers and hearths, grates etc.,

- construction of machine tools: bodies, gears, shafts, transmission gears, bodies of both parts of the mechanisms and electrical equipment (in this section, cast iron castings constitute up to $90 \%$ of the total construction weight),

- metallurgy: bodies of typical machines and technological devices. Ingot moulds, rollers, furnace spouts and doors, connectors and tooling for rolling mills, press shops and partially forges are made from cast iron,

automotive industry: engine blocks, bodies of transmission gears, crankshafts and parts of brake units,

- shipbuilding industry: pipe ducts, turbines, parts of engines, pumps, line rolls etc.,

- electrotechnics: bodies of engines and generators, electrical units cases and small parts of electric and electronic equipment.

The scope of application of the cast iron is very wide. Table 1 presents a selection of applications of cast iron with the exemplary chemical composition.

Table below presents the approximate chemical composition of popular castings [2]. 
Table 1: Types of castings with their chemical composition [2].

\begin{tabular}{|c|c|c|c|c|c|}
\hline \multirow[t]{2}{*}{ Types of castings } & \multicolumn{5}{|c|}{ Chemical composition \% } \\
\hline & C & Si & $\mathrm{Mn}$ & $P_{\max }$ & $\mathbf{S}_{\max }$ \\
\hline $\begin{array}{l}\text { Construction industry and household castings (columns, window frames, } \\
\text { kitchenware, irons, sewer pipes) }\end{array}$ & $3,3 \div 3,6$ & $1,8 \div 2,5$ & $0,6 \div 1,0$ & $0,3 \div 1,0$ & $0,08 \div 0,12$ \\
\hline $\begin{array}{l}\text { Machine castings (protective casings, small-diameter press wheels, parts } \\
\text { of agricultural machinery, sewing machines, typewriters and calcula- } \\
\text { ting machines, discs, castings for small machine tools) }\end{array}$ & $3,2 \div 3,6$ & $1,5 \div 3,0$ & $0,6 \div 1,0$ & $0,3 \div 0,8$ & $0,08 \div 0,12$ \\
\hline $\begin{array}{l}\text { Machine castings (parts of tractors, machine tools, agricultural machi- } \\
\text { nery, large press-and flywheels, bodies of pumps) }\end{array}$ & $2,8 \div 3,4$ & $1,3 \div 3,0$ & $0,6 \div 1,0$ & $0,2 \div 0,8$ & $0,08 \div 0,12$ \\
\hline Brake blocks & $\sim 3,20$ & 1.50 & 0.80 & 0.60 & 0.15 \\
\hline Enamelware & $3,6 \div 3,8$ & $2,5 \div 2,8$ & 0.50 & 0.80 & 0.09 \\
\hline Glass moulds & $\sim 3,00$ & 2.50 & 0.60 & 0.30 & 0.05 \\
\hline Piston rings & $3,2 \div 3,6$ & $1,8 \div 2,0$ & $0,7 \div 0,8$ & 0.50 & 0.06 \\
\hline Piston bushes & $\sim 3,20$ & 2.0 & 0.60 & 0.40 & 0.09 \\
\hline Cast iron coquilles for Al alloys castings & $\sim 3,50$ & 2.0 & 0.50 & 0.40 & 0.10 \\
\hline Cast iron coquilles for Cu alloys castings & $\sim 3,50$ & 1.60 & 0.70 & 0.25 & 0.08 \\
\hline Hammer dies & $2,7 \div 3,0$ & $2,0 \div 2,5$ & 0.50 & 0.60 & 0.06 \\
\hline Press dies & $2,7 \div 3,0$ & 1.0 & 0.50 & 0.60 & 0.06 \\
\hline Friction clutches & $3,5 \div 3,7$ & $2,0 \div 2,4$ & $0,6 \div 0,7$ & 0.70 & 0.10 \\
\hline Car cylinders & $\sim 3,25$ & $2,0 \div 2,3$ & 0.7 & 0.50 & 0.07 \\
\hline Steam cylinders & $\sim 3,50$ & $1,2 \div 2,0$ & $0,6 \div 1,0$ & $0,3 \div 0,5$ & 0.10 \\
\hline Pneumatic cylinders & $3,0 \div 3,4$ & $1,0 \div 1,9$ & $0,7 \div 0,9$ & $0,3 \div 0,5$ & 0.10 \\
\hline Cast iron for spheroidization & $3,4 \div 4,2$ & $1,0 \div 4,0$ & $0,2 \div 0,6$ & 0.10 & 0.07 \\
\hline Malleable white cast iron & $2,7 \div 3,2$ & $0,5 \div 1,0$ & $0,3 \div 0,5$ & 0.10 & 0.22 \\
\hline Malleable black cast iron & $2,6 \div 2,9$ & $0,8 \div 1,2$ & $0,4 \div 0,6$ & 0.10 & 0.16 \\
\hline Malleable black cast iron (Z-Metal, max. 0,2\% Cr) & $2,2 \div 2,7$ & $0,8 \div 1,0$ & $0,8 \div 1,2$ & 0.20 & 0.15 \\
\hline Malleable black cast iron (abrasion resistant, max. 0,1\% Ti) & $2,4 \div 2,7$ & $0,8 \div 1,0$ & $0,8 \div 1,0$ & 0.10 & 0.12 \\
\hline
\end{tabular}

\section{Surface Layer \\ Classification of the surface layer and the technological surface}

Surface layer is the layer of the material limited by the outer (true) surface of the object (product), containing this surface and the part of the material below this surface, exhibiting changeable physical and sometimes chemical features in comparison to the rest of the material inside the product (core of the material).

The surface layer exists in all industrial products, especially in machines and technical devices [6, 7, 34].

According to Hebdy, M. the entirety of the surface layer (SL) may be described by the following formula:
$S_{W W}=f\left(\sigma, \frac{d \sigma}{d h}, H, \frac{d H}{d h}, S, \frac{d S}{d h}, F, \frac{d F}{d h}\right.$,

$\left.T, \frac{d T}{d h}, C, \frac{d C}{d h}, E, W\right)$

where:

$\boldsymbol{\sigma}$ - field of internal stresses of the surface layer SL; $\boldsymbol{d} \boldsymbol{\sigma} / \boldsymbol{d} \boldsymbol{h}$ - gradient of the internal stresses of the SL; $\boldsymbol{H}$ - area of the SL material hardness; $\boldsymbol{d H} / \boldsymbol{d} \boldsymbol{h}$ - gradient of the SL material hardness; $\boldsymbol{S}$ - SL material structure $\boldsymbol{d} \boldsymbol{S} / \boldsymbol{d} \boldsymbol{h}$ - structural changes in the cross section of the SL; $\boldsymbol{F}$ - fragmentation of the crystallites of the SL; $\boldsymbol{d} \boldsymbol{F} / \boldsymbol{d} \boldsymbol{h}$ - gradient of fragmentation of the crystallites of the SL material; $\boldsymbol{T}$ - SL material texture; $\boldsymbol{d} \boldsymbol{T} / \boldsymbol{d} \boldsymbol{h}$ - changes in the texturization of the cross section of the SL; $\boldsymbol{C}$ - chemical properties 
of the SL material; $\boldsymbol{d} \boldsymbol{C} / \boldsymbol{d} \boldsymbol{h}$ - changes in the chemical properties of the SL material; $\boldsymbol{E}$ - free energy of the surface, dependent on the state of the SL; $\boldsymbol{W}$ - constructional flaws of the SL material (macrodiscontinuities)

The most important parameters characterizing the properties of the surface layer are the internal stresses, surface crumple, structure of the material and the fragmentation of the crystallites. These parameters bind or condition the values of the remaining parameters, as in the formula (1). In accordance with this formula, in order to present precise characteristics of the surface layer structure, the values, distribution, gradients and depths of all the parameters included in this formula have to be measured. A simplified characteristic of the state of the surface layer (Fig. 1) may be achieved after preparing: a profilogram of the surface, a photograph of the surface, a location of the microhardness imprints on the cross section of the surface layer and charts of the location of hardness and location of internal stresses in the cross section of the surface layer $[10,25,32,33,35]$.

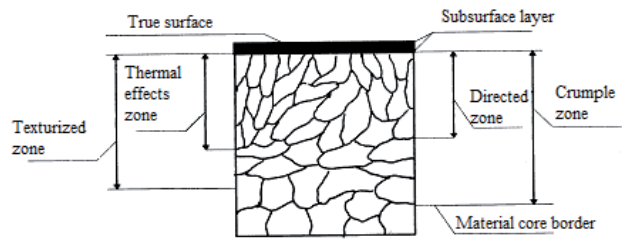

Fig. 1: Simplified scheme of the surface layer after machining [10, $25,35]$.

The subsurface layer, i.e. the layer directly under the stereometric surface, is an area of adsorbed molecules of gas, liquid or solid bodies (e.g. molecules of air, particles product material, pollution etc.) Moreover, this layer contains also a layer of oxides and other compounds of machined metal, as well as chipped molecules of crystalline lattice. Altogether, the thickness of this layer is very small, usually not higher than $80 \ddot{A}$, which justifies treating these two layers jointly. It should be emphasized, that the subsurface zone plays a very important role, for example in the wear processes. The fundamental part of the surface layer is the area the machined material plastically deformed by the forces involved in the technological process (the crumpled zone). The thickness of this zone may vary from a few hundredths to tenths of a millimeter, depending on the method and conditions of machining $[7,28,29,30]$.

The example of any product shows that:

- The surface layer is different from the core of the material. For example, the picture shows distinct changes in the microstructure of the zones of the surface layer (SL) compared to the core (C).

- The properties of the surface layer depend on the technological process applied in creation of the product; e.g. it is possible to observe distinct changes in the thickness of the so-called white zone of particularly hard surface layers, resulting from changes in the conditions of machining.

It can be also demonstrated that [24, 29, 33]:

- there are no contraindications against shaping the operating surface of the product in the surface layer of spheroidal cast iron casting,

- shaping the operating surface of the product in the surface layer of rough spheroidal cast iron casting does not decrease its properties".

In the metrology of the surface layer it is agreed that the layer of the product material close to its surface and the surface itself have different physicochemical properties than the deeper layers of the material, which are the so-called core (C). This layer is called the surface layer (SL). There is a relationship between the geometric structure of the surface and the wear strength (micro-notches). Similarly, it is possible to demonstrate a general influence of the state of the surface layer on the corrosive, erosive and other types of wear. It leads to a conclusion that it is the state of the surface layer that has a significant influence on the wear process, and, by that, on the durability and reliability of the parts of machines and devices. In order to reveal the importance of the surface layer in the machine technology, it has to be taken into account that every technological process, as a result of which a product with a required shape is created, creates also a surface layer with specific features (geometric structure of the surface and physicochemical properties of the zones in particular), which depend on the realization conditions of the process. Each processing method (turning, sanding, shearing etc.) is characterized by a certain geometric structure of the processed surface, particularly by its roughness.

An important aspect influencing the state of the surface layer is the microstructure of the zones, their microhardness and internal stresses, which are significantly different from the corresponding properties 
of the core of the material, even when the thickness of the surface layer reaches up to tens of micrometers [6].

The surface layer has a crucial influence on the wear of the product. At the same time, this layer is dependent on the technological conditions of the product creation. The technological processes should be designed and realized in a way that not only ensures achieving the necessary precision of dimensions and shape, but also results in creation of a surface layer with optimal performance characteristics, and, above all, ensures its necessary abrasive hardness and wear fatigue resistance.

\section{A Selection of Properties of the Surface Layer}

The surface layer of the processed product and its quality is characterized by its physical properties and by stereometric properties of the processed surface.

The physical properties of the surface layer are:

- microstructure, fibrosity and its distribution and size in the area of the surface layer,

- plastic deformation, i.e. crumple and related changes in toughness and resistance (surface strengthening),

- resultant stresses (also known as the final or post-machining stresses), and their location in the surface layer and the base material.

Changes in the properties of the base material and creation of the surface layer are caused by:

- field of stresses generated by the cutting forces,

- field of temperatures generated by the heat resulting from cutting,

- inner and outer friction.

\section{The Structure of the Surface Layer}

Based on the definition of the surface layer, it is accepted that the fundamental elements of its structure are (Fig. 2):

the surface of the surface layer (SLS),

- the areas of the surface layer located inside the material, beneath the real surface (SLA).

Consequently, the structure of the surface layer contains a system of elements forming:

\section{- geometric structure of the surface (GSS)}

- physicochemical structure of the surface layer areas (PSA)

Geometric structure of the surface is a system of geometric elements of the surfaces created during the technological process of production, or during the project usage.

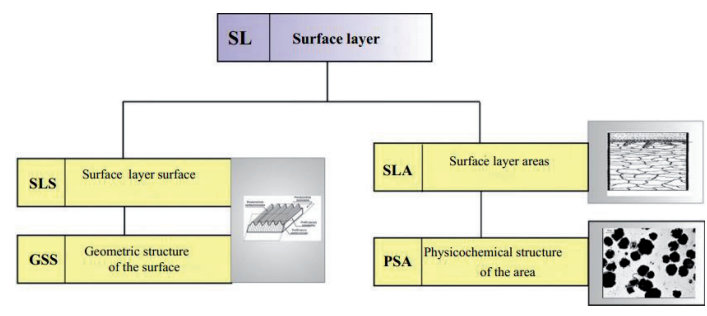

Fig. 2: Fundamental elements of the surface layer structure [6, 24].

Usually the geometric structure of the surface is characterized by elevations and cavities of different shape, size and location, resulting from physical effects occurring during the product creation (forces and deformations, thermal effects, processes of decohesion of the processed material etc.) [6]. A particular feature of the geometric structure of the surface is limiting it to geometric elements, which means that the quantities (parameters) characterizing this structure are mostly measures of length and angle. During the analysis of the physicochemical structure of the surface layer areas (PSA) it has to be noted, that the area of the surface layer is a part of this surface layer, volume of which is designated by the existence of a given feature $[8,29,32,33]$. The most important features characterizing the area of the surface layer are the measurable quantities, including quantities of a physical and sometimes chemical character. This causes the need to use an equal term in this case: the physical properties of the source layer. This term is equated with the notion of the surface layer areas (SLA) and the description of their structure, i.e. a physicochemical structure of the surface layer areas (PSA), or, shortly, the structure of the areas of the surface layer. However, it has to be emphasized that irrespective of the dominating significance of the physicochemical features of the areas of the surface layer, the description of their structure (PSA) covers also the geometric location of these areas, presenting their shape, dimensions and location in the volume of the surface layer. First of all, it is stressed that the individual areas determined by the existence of a particular physicochemical feature may fully or partially overlap or gradually interpenetrate - correspondingly to the changes in the quantities characterizing specific surface layer areas. Differentiating between the geometric structure of the surface (GSS) and the physicochemical structure of the surface layer areas (PSA) allows to character- 
ize each of them in detail, thus creating the conceptual basics of their metrology.

\section{Changes in the Structure of the Surface Layer}

Achieving phase and structural transitions is possible by maintaining the parameters of the process - high temperature and long time. For example, in subtractive manufacturing processes such as machining, the temperature of the surface layer may exceed $1000^{\circ} \mathrm{C}$. This means that the temperatures of machining may be high enough for phase and structural transitions. The duration of these temperatures is related to the time the blade touches the machined material. Within the range of commonly used machining speeds, the duration of the temperature on a $1 \mathrm{~mm}$ segment may be estimated between $2 \mathrm{~ms} / \mathrm{mm}$ to $0.03 \mathrm{~ms} / \mathrm{mm}$. These are very short times from the point of view of the requirements of phase and structural transitions. Because of that, these effects are very limited. The most common structural changes during the machining process of steel are the pearlitic and martensitic transformations, i.e. quenching and tempering. In proper machining conditions, these effects occur at small depths of approximately hundredths of a millimeter. Changes in the properties of the surface layer resulting from the structural changes are usually undesirable, mainly because in most cases they are uncontrolled and unknown. During the machining of quenched steel, parts of the surface layer get tempered and quenched again. Therefore, the surface layer consists of several parallel areas with different structure and properties. In order to protect the surface layer against undesirable structural changes, it is best to choose such conditions for the process which allow to lower the temperature of machining.

\section{Stresses}

\section{Classification of internal stresses (Fig. 3)}

The type of internal stresses is rather a conventional term, which accounts for the field (PN-M04250:1998) on which the values of internal stresses change, especially in the areas of the surface layer.

The classification of internal stresses by E. Orowan includes:

- macrostresses (body stresses): resulting from any external strain. These stresses balance out in the total volume of the strained element (a sample or a prod$u(t)$,
- microstresses: resulting from heterogeneity of the microstructure of the material.

This classification is not very precise, especially with respect to microstresses. An alternative classification was developed by N.N. Davidenkov, and it includes:

Type I stresses: stresses balanced in the areas commensurable with the dimensions of the examined material in the macro scale: sample - product (Type I stresses correspond to the conceptually equivalent macrostresses),

Type II stresses: stresses which balance each other in the areas corresponding to a particular number of grains, or even a part of one grain of the surface layer areas microstructure,

- Type III stresses: stresses which balance each other in the areas corresponding to the dimensional parameters of the crystalline lattice of the material.

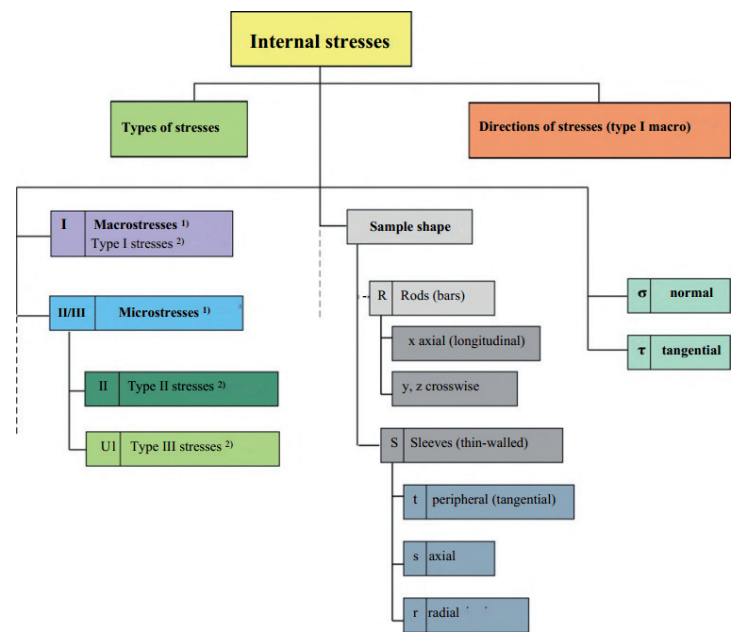

1) E. Orowan's classification

2) N.N. Davidenkov's classification

Fig. 3: Classification of internal stresses [6]

N.N. Davidenkov's classification covers also the type I and type II stresses (Fig. 4).

Considering the particularly important role of the macrostresses (type/ stresses) in the characteristics of the mechanical quantities of the surface layer areas, it may be assumed that these stresses do not change significantly, within the range corresponding to the size of a single grain of the examined surface layer areas microstructure. However, one has to be aware of at least an approximate order of magnitude of the 
analyzed quantities; taking the grain size: $\bar{D} \approx 30 \mu \mathrm{m}$ and the parameter of the lattice (iron $\alpha$ A2 lattice) $\mathrm{a}=0,295 \mathrm{~nm}$, a huge difference of scale $\bar{D} / a \approx 1,0^{5}$ is observed. A solution to that is to assume the above definitions of the internal stresses to be completely conventional, and at the same time, determining the measurement methods precisely. When choosing the measurement method, the type of the physical quantity considered to be equivalent to the notion of stresses is chosen, and the method of determining its value is specified. This allows to formulate comparable quantitative assessments of the internal stresses [6].

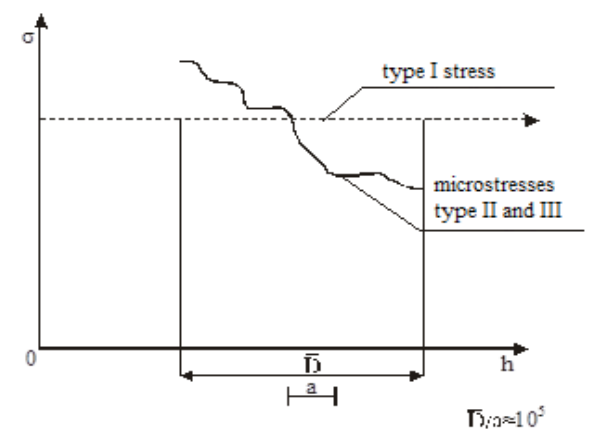

where: $\bar{D}$ - grain diameter, a - crystalline lattice parameter, $\sigma$ - stresses

Fig. 4: Hypothetical assumptions identifying the types of internal stresses [6].

The direction of internal stresses, also known as the type of stresses is a crucial criterion of classification. The direction of internal stresses is determined first of all in relation to the macrostresses (type I stresses). The following division distinguishes (Fig. 5):

\section{- model of shape of the sample,}

- the location of the section of the surface layer.

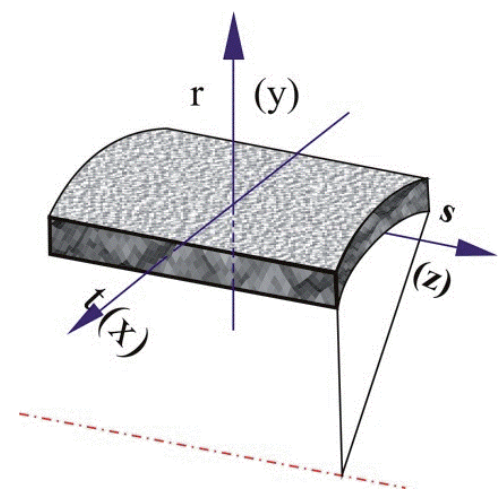

Fig. 5: Directions of internal macrostresses in thin-walled sleeves [6].
Various shapes of the sample are possible (rod, bar, thin- and thick-walled sleeve, disk etc), though the important thing is its ideal model related to the method of theoretical analysis of the stresses. With respect to the method of measurement of the internal stresses in the surface layer, it is proper to identify (Fig. 5) [6, 26]:

sleeves (thin-walled), with respect to which circumferential-tangential stresses $t$, axial stresses $s$, and radial stresses $r$ can be identified.

The direction of stresses may also be determined directly with respect to the location of the section of the surface layer, in which the parameters of its characteristics are specified. Since the location of this section may be justified by another factors, e.g. it may be perpendicular to the traces of machining, in accordance with the recommendations obligatory in determining the roughness profile of the surface, it is possible to distinguish [7]:

\section{- internal stresses normal to the section of the sur-} face layer $\sigma$,

- internal stresses tangential to the section of the surface layer $\tau$.

In the case of the microstresses (type II and III stresses), identified by X-ray methods (diffraction tests), the role of direction is fulfilled by the specified location of the crystallographic plane, considered when determining the stresses. The above statements additionally justify the decisive importance of the internal stresses measurement method in assessing their type and direction. The methods of internal stresses measurements may be various, and when assessing their actual usefulness in measuring the constant states of internal stresses of the surface layer areas of typical products, two fundamental methods of internal stresses measurement will be taken into account, and these are:

\section{- mechanical method, \\ - $x$-ray (diffraction) method, \\ -Optical method [26, 27].}

Physical fundamentals of both proposed methods are that from many physical effects which measurable changes may be correlated with the changes of internal stresses in the surface layer, occurring in the specified distances $h$ from the surface, two effects which are the measure of the deformations caused by these stresses were chosen. These are $[11,12,26$, 27]:

- changes in deformation of the sample in the macro scale (mechanical methods), 
- changes in the $x$-ray diffraction ( $x$-ray methods).

Each of these conceptions of the internal stresses measurement is characterized by specific positive and negative features, describing their applications in measuring the mechanical quantities of the surface layer characteristics.

\section{Research}

\section{Preparing the samples for research}

A cast iron casting (EN-GJS-500-7 $\left(R_{m}=500 \mathrm{~N} / \mathrm{mm}^{2}\right.$; $\left.R_{p 02}=320 \mathrm{~N} / \mathrm{mm}^{2} ; A=7 \%\right)$ ) was used in order to prepare the samples (Fig. 6) necessary for the research. This casting was used for production of various preforms and glass moulds (production of glass containers - for food, pharmaceutical and chemical industries).

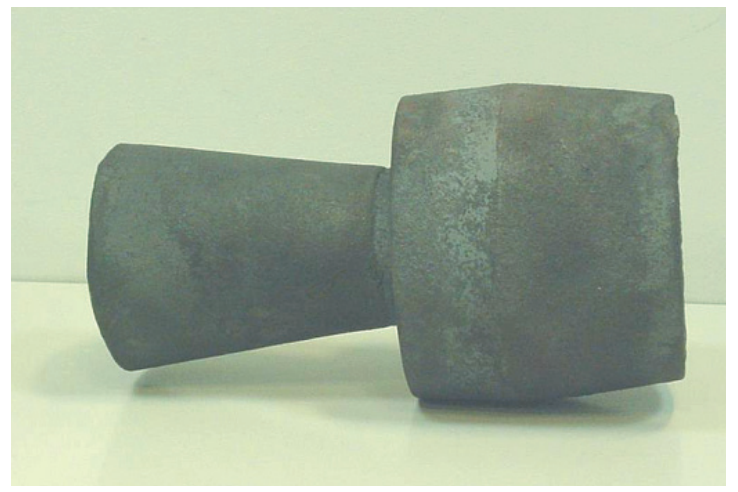

Fig. 6: GJS-500-7 spheroidal cast iron casting.

The examined casting was machined. The first step was to cut the casting into two symmetrical parts. The surfaces were shaped by turning. The casting was shaped according to the working drawing which was prepared for the machining (Fig. 7).

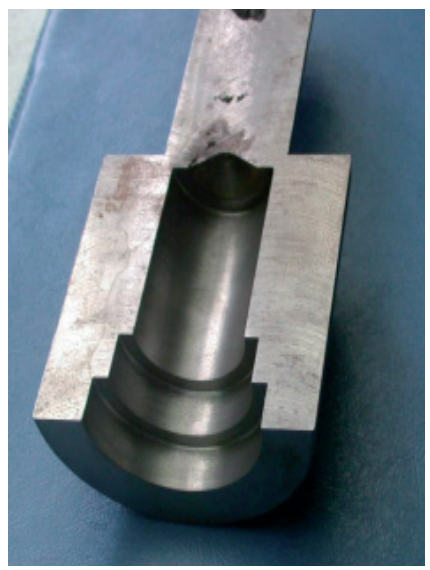

Fig. 7: The machined casting.
The half-products (two symmetrical parts) prepared for further machining were then weld surfaced. The course of the weld surfacing process:

- the preform was heated to about $800^{\circ} \mathrm{C}$, - a layer of powder weld surfaced material was placed on the heated preform with a gas burner (Fig. 8).

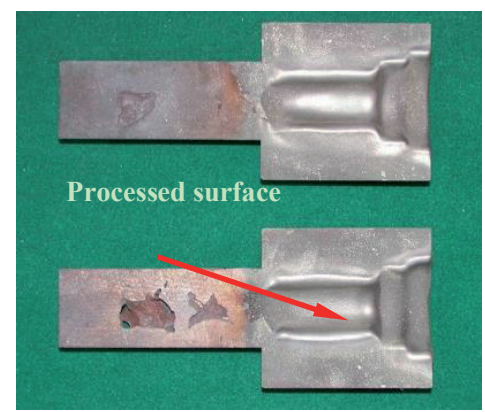

Fig. 8: The powder weld surfaced half-product with the base surface marked.

After powder weld surfacing process, the half-products were further machined by turning. The outer surface of the half-product was the base surface.

Machining parameters:

\section{- feed rate $0.12 \mathrm{~mm} / \mathrm{rev}$.,}

\section{- speed 260 RPM.}

A process of continuous cooling to $30^{\circ} \mathrm{C}$ was applied during turning.

The next step of preparing the samples was to cut and turn rings with intended dimensions from one of the half-products. Six half-rings with the following geometry were created in the machining process:

- half-ring I- $\varnothing 57 \times \varnothing 52 \times 10$,

- half-ring $\|-\varnothing 47 \times \varnothing 42 \times 10$,

- half-ring III - $\varnothing 39 \times \varnothing 37 \times 10$,

- half-ring IV - $\varnothing 37 \times \varnothing 33.2 \times 10$,

- half-ring $V-\varnothing 37 \times \varnothing 32.6 \times 10$,

- half-ring VI - $\varnothing 37 \times \varnothing 32 \times 10$.

The next stage was to prepare the samples for etching. After creating the half-rings (samples), two points were marked with a punch marker, which enabled measuring the distance $b$ and deflection curve f.

A process of etching of all the prepared samples was the next stage of the research. Etching of the samples was performed in specially prepared station in the chemistry lab. The process of etching was performed on a station called the fume hood (it is a ventilation device that is designed to limit exposure to hazardous chemical compounds). The solution, in 
which the samples were etched (nitric acid $\mathrm{HNO}_{3}$ ).
I

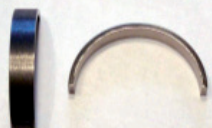

III

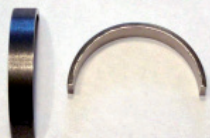

V

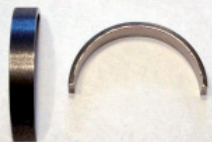

II

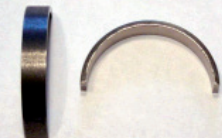

IV

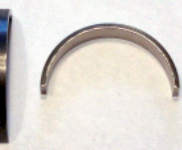

VI

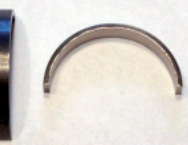

Fig. 9: Samples in the form of half-rings.

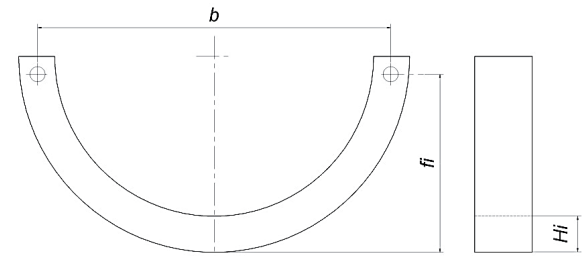

Fig. 10: Measurement sample.

The following steps had to be taken while preparing the samples for etching:

\section{FIRST ETCHING}

- cleaning the samples with extraction naphtha,

- inserting the samples (half-rings) into melted paraffin,

- removing the wax from the internal surface (without touching the remaining edges)

- cleaning the internal surface with extraction naphtha,

- etching the samples in the solution of nitric acid for 5 minutes.

\section{SECOND ETCHING}

- cleaning the samples with extraction naphtha,

- inserting the samples (half-rings) into melted paraffin,

- removing the wax from the internal surface (without touching the remaining edges)

- cleaning the internal surface with extraction naphtha,

- etching the samples in the solution of nitric acid for 5 minutes.

Etchings third to fifth were performed similarly as the second etching. The acid was washed from the sam- ples before examination after each etching. Next, after 24 hours, the remaining paraffin was washed from the samples, and the samples were washed with extraction naphtha. After these actions, the half rings were measured. The length measurements were performed on the MWD workshop microscope.

\section{The Results of the Davidenkov's Method Research on the Internal Stresses}

Picture 11 is a chart showing the changes in the stresses of the examined samples collectively.

\section{Results and Discussion}

The following conclusions and statements were established after the research:

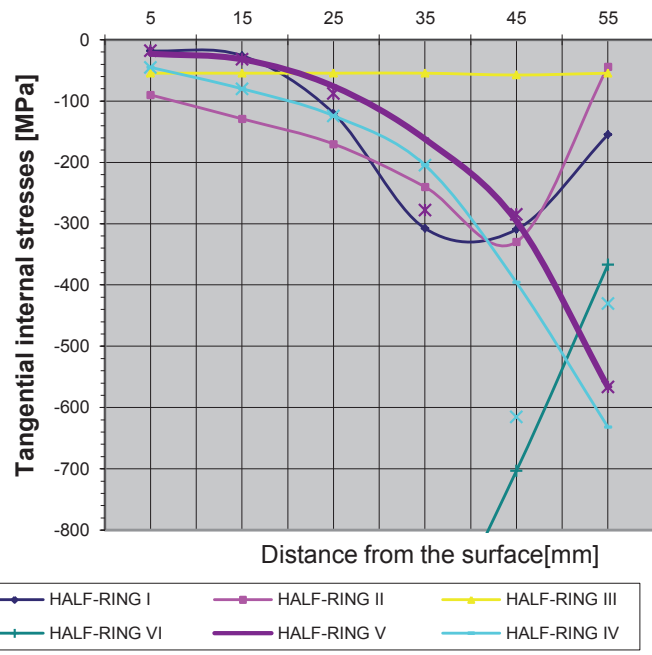

Fig. 11: Changes in the internal stresses of the weld surfaced surface layer and cast iron surface layer.

1. It is known, that the process of weld surfacing causes stretching stresses. The process of machining has a dominating influence on changes in these stresses in the weld surfaced area (on the thickness of up to $50 \mu \mathrm{m}$ ) Turning of the surface, applied in this case, resulted in the development of tangential compressive stresses.

2. The value of these stresses depends on the thickness of the weld surfaced layer, as well as the core (here - spheroidal cast iron):

- increase of the thickness of the cast iron base (core) causes a significant increase in the compressive stresses. The research proved that the increase of thickness of the cast iron base (half-ring I - 16mm, half-ring II - $21 \mathrm{~mm}$, half-ring VI-26 mm), causes a significant increase of the compressive stresses (from 200 to $1400 \mathrm{MPa}$ ). This effect may be explained by the improvement of the cooling conditions and the fact, that the core absorbs tempera- 
ture,

- the influence of thickness of the weld surfaced layer on stresses is similar to the influence of the base material (in this case spheroidal cast iron). It has to be stated that the increase of thickness of the weld surfaced layer causes the increase of compressive internal stresses.

Basic factor influencing the occurrence of stresses (on the thickness of up to $0.1 \mathrm{~mm}$ ) is the machining process. It can be also stated that turning as a method of finishing machining has a better influence on stresses compared to grinding, because the weld surfacing process results in the occurrence stretching stresses, while grinding leads to further increase of the stretching stresses. Turning, on the other hand, results in compressive stresses, therefore it does not add further stresses which could result in cracking of the surface layer.

\section{References}

[1] Technologia szkła. Praca zbiorowa pod redakcją dr inż. Jana Wójcickiego - Wyd. Arkady Warszawa 1987r.

[2] Podrzucki Zz. Żeliwo. Struktura, właściwości, zastosowanie. Wyd. ZG STOP, Kraków 1991 r.

[3] Metaloznawstwo. Przybyłowizz. K. WNT. Warszawa 2006r.

[4] $\quad \mathrm{PN}-75 / \mathrm{H}-04661$

[5] Stanisław, M.: Obróbka metaliz materiałoznawstwem. Wyd. PWN, Warszawa 1996r.

[6] Górecka, R., Polański, Z:. Metrologia warstwy wierzchniej. Wyd. WNT 1996r.

[7] Kaczmarek, J.: Podstawy obróbki wiórowej, ściernej i erozyjnej. Warszawa WNT 1970r.

[8] PN-M-04250:1987. Warstwa wierzchnia- Terminologia

[9] Trybologia Hebda M., Wachal, A. - WNT, Warszawa 1980r.

[10] Burakowski, -., Wierzchoń, T:. Inżynieria powierzchni metali, WNT,W-wa 1995.

[11] Przegląd Mechaniczny Kaczmarek J. - Wpływ obróbki mechanicznej na własności warstwy wierzchniej.. $1962 \mathrm{nr}$ 13 s. 32-39.

[12] Kaczmarek J. - Wpływ stanu naprężeń na ścieranie luźnym ścierniwem. Warszawa: WNT, 1970.

[13] Podstawy konstrukcji maszyn. Dietrich M. Tom 1. Praca zbiorowa WNT) Rok: 2006

[14] Hebeda, M., Keller, Cz. - Dyfraktometryczna i mechaniczna metoda pomiaru napręzeń własnych w warstwie podpowierzchniowej próbek szlifowanych. Warszawa: 1963WAT n 7s. 131-138.

[15] Zeszyty Naukowe AGH. Hebeda M. - Wybrane metody eksperymentalnej analizy napręzeń własnych w warstwie wierzchniej. 1967 z. 22 s. 38-46.

[16] Tarcie, smarowanie i zużycie części maszyn. Hebeda M., Janecki J. - Warszawa WNT 1969 r.

[17]. Katarzyński, S., Kocańda, S.,Zakkzewski, M. - Badania własności mechanizznych metali. Warzzzawa WNT 1967r

[18] Pachczyński.P-Mitutoyo PL-11001

[19] Archiwum Technologii Maszyn i Automatyzacji. Dzierwa A., Korzyński M. - Badania możiwości poprawy przez kulowanie właściwości zmęczeniowych elementów chromowanych. Poznań $2007 \mathrm{Vol} .27 \mathrm{nr} 1 /$

[20] Markowski, S., Skrzypiński, A. - Wybrane zagadnienia warstwy wierzchniej w budowie maszyn. Kraków, Akademia Górniczo-Hutnicza 1974r.

[21] Praca doktorska. Pakosiewicz B. - Badanie wpływu warunków skrawania przy toczeniu na stan warstwy wierzchniej i jej niektóre własności użytkowe. Politechnika Krakowska 1972r.

[22] Polańskiz.. Elektroiskrowe drążenie metali elektrodami kompensacyjnymi. WarszawaWNT 1965 r.

[23] Praca doktorska. Zachwieja T. - Badania niektórych zależności technologizznych w celu optymalizacji warunków elektrochemizzno-ściernej obróbki węglików spiekanych ściernicą diamentową., Akademia Górniczo-Hutnicza 1969r.

[24] Praca doktorska. Kuryło P. Badanie włáciwości technologicznych i eksploatacyjnych warstwy wierzchniej odlewu zżeliwa sferoidalnego. Politechnika Poznańska 2003 r.

[25] Młynarczyk, A., Jakubowski, J.: Obróbka powierzchniowa i powłoki ochronne. Wyd. Politechniki Poznańskiej, Poznań 1998.

[26] Trebuňa, F., Masláková, K., Frankovský, P.: Residual stress measurements 2011. In: MMaMS 2011: Modelling of Mechanical and Mechatronical Systems: proceedings of the 4th international conference: Herl'any, Slovakia, 20 - 22. 9. 2011. Košice: TU, 2011 s. 487-491. ISBN 978-80-553-0731-2

[27] Trebuňa, F., Frankovský, P., Bocko, J., Pástor, M.: New possibilities of using PhotoStress method. 2011. In: Acta Mechanica Slovaca. Roč. 15, č. 4 (2011), s. 44-50 ISSN 1335-2393

[28] Janik, S., 2001. Analiza stanu warstwy wierzchniej odlewu ż̇eliwa szarego. Editor. Wyższej Szkoły Pedagogicznej w Zielonej Górze, Zielona Góra.

[29] Kuryło, P., Janik, S., 1999. Model warstwy wierzchniej surowego odlewu Żeliwnego - Żeliwo sferoidalne 500-7. 4-ta International Scientific Conference - Wpływ Technologii na stan warstwy wierzchniej-WW'99. Lubniewice-Gorzów Wlkp.

[30] Kuryło, P., Janik, S., 2000. Aspekty zastosowania Żeliwa sferoidalnego jako tworzywa na formy szklarskie: Rozvoj Technologie Obrabania -RTO 2000: 3. Medzinarodna vedecka konferencia. Kosice, Słowacja, Kosice, p. 39.

[31] Kuryło, P., Janik, S.; Utilization of propriety of surface layer of founding from spheroid cast irons 500-7; w: Proizvodstvo: Technologija: Ekologija - PROTEK 2002 Mezdunarodnaja naucno-prakticeskaja konferencija. Sbornik trudov konferencii. Moskva, Rosja, 2002-Moskva : MGGU "Stankin", 2002. ISBN 5-8037-094-0-T.

[32] Kuryło, P., Janik, S.; The abrasive wear of spheroid cast iron 500-7; Nove trendy v prevadzke vyrobnej techniky 2002: V.medzinarodna vedecka konferencia. Presov, Słowacja, 2002 .- Kosice: Fakulta vyrobnych technologii Technickej university Kosice, 2002-ISBN: 80-7099-996-3, s. 176-181

[33] Kuryło, P., Janik, S.; Utilization of propriety of surface layer of founding from spheroid cast irons 500-7: Proizvodstvo: Technologija: Ekologija - PROTEK 2002: Mezdunarodnaja naucno-prakticeskaja konferencija. Sbornik trudov konferencii. Moskva, Rosja, 2002 .- Moskva: MGGU“Stankin”, 2002 .- ISBN: 5-8037-094-0T. 2, s. 669-675.

[34] Kuryło, P., Janik S.; Ścieralność żeliwa sferoidalnego 500-7; Studia i Materiały (Technologia maszyn).- 2002, T. 20, nr 1, s. 245-251: bibliogr. rys. wykr. summ(Technologia Maszyn). 2002, T. 20, nr 1, s. 245-251

[35] Zeszyty Naukowe Politechniki Rzeszowskiej. Janik Stanisław, Wieczorowski Kazimierz. Wykorzystanie strefy przejściowej warstwy wierzchniej odlewu żeliwnego dla podwyższenia własności eksploatacyjnych wyrobu. 1995, z. 44. 